\title{
Polarographic Evidence of the Production of Polythionates During the Bacterial Oxidation of Thiosulphate
}

\author{
BY EILEEN S. PANKHURST \\ London Research Station, The Gas Council
}

(Received 1 August 1963)

\begin{abstract}
SUMMARY
A polarographic technique and Starkey's alkali method have been applied to the qualitative analysis of thiosulphate, trithionate and pentathionate and to the quantitative analysis of tetrathionate in filtrates of bacterial cultures grown in an inorganic medium containing sodium thiosulphate. Five strains of autotrophic thiobacilli and one strain of a heterotrophic bacterium produced polythionates. During thiosulphate oxidation by two autotrophic strains which resembled Thiobacillus thioparus, tetrathionate, small amounts of trithionate, pentathionate and abundant elemental sulphur were produced and the $\mathrm{pH}$ fell from $c .7 \cdot 0$ to $c .3 \cdot 0$. In cultures of one of the three autotrophic strains which resembled $T$. thiocyanoxidans, about half as much tetrathionate, with even smaller amounts of trithionate and pentathionate, was found; abundant sulphur was precipitated and the $\mathrm{pH}$ fell to $c$. $4 \cdot 0$. In cultures of the two other strains resembling $T$. thiocyanoxidans, small amounts of tetrathionate were detected only occasionally; trithionate and pentathionate were not found, sulphur was deposited and the $\mathrm{pH}$ fell to $c$. 4.5. Much tetrathionate, as well as trithionate and pentathionate, were all readily identified in cultures of the heterotrophic organism; the $\mathrm{pH}$ rose to $c .8 \cdot 7$ and no sulphur was formed.
\end{abstract}

\section{INTRODUCTION}

Since bacteria oxidizing thiosulphate were first described and isolated (Nathansohn, 1902; Beijerinck, 1904), the role of polythionates as possible intermediates has been debated. Over a period of many years several pathways for thiosulphate oxidation have been proposed, based on the results of tests for intermediates. Much of the work on thiobacilli has been reviewed by Baalsrud (1954), by Lees (1955), by Starkey (1956), by Vishniac \& Santer (1957) and more recently by Peck (1962) and by Vishniac \& Trudinger (1962). The intermediates and end-products which have been detected by various workers fall into the five main groups which are summarized in Table 1.

Numerous methods have been used to detect polythionates. Nathansohn (1902) made use of the solubility of the barium salts of thionates and of their subsequent oxidation by bromine. Starkey's quantitative determinations (1935a) depended on the reactions of trithionate, tetrathionate and pentathionate with sulphite, cyanate and mercuric chloride; he also developed a qualitative test, subsequently much used, in which polythionates are converted by treatment with alkali to sulphite and thiosulphate which are then titrated with iodine $(\mathbf{1 9 3 4} b)$. Parker $\&$ Prisk (1953) used similar methods. Vishniac (1952) used mercurous nitrate as an 
Table 1. Summary of intermediates postulated or found during the bacterial oxidation of thiosulphate
Intermediates
End-products
Organism
Reference

Group 1

One or more polythionates

\section{Group 2}

Not identified One or more of the following: sulphate, sulphuric acid, sulphur

\section{Group 3 \\ Pyrosulphite, pyrosulphate}

\section{Group 4 \\ Sulphite, sulphide}

Sulphate, sulphuric acid

Sulphate
One or more of the following: sulphate, sulphuric acid, sulphur
Unnamed species (probably thioparus) isolated by Nathansohn (1902)

Thiobacillus thiooxidans isolated by Lipman, Waksman \& Joffe (1921), Waksman \& Joffe (1922)

$T$. concretivorus isolated by Parker (1945)

Thiobacillus X (thioparus or neapolitanus) isolated by Parker (1947)

\section{T. thioparus}

Thiobacillus X

T. thioparus isolated by Parker (1947) (Thiobacillus X)

Nathansohn (1902)

T. thioparus, NCIB 8370 (Starkey's original non-motile strain)

$T$. thiocyanoxidans isolated by Happold, Jones \& Pratt (1958)

T. thioparus isolated by Vishniac (1952)

$T$. thioparus isolated by Starkey $(1935 b)$

T. thioparus, NCIB 8370 (Starkey's original non-motile strain)

$T$. denitrificans isolated by Baalsrud \& Baalsrud (1954)

$T$. thiocyanoxidans isolated by Happold et al. (1958)

T. novellus isolated by Starkey $(1935 b)$

Thiobacillus $\mathrm{X}$

T. thioparus

Jones \& Happold (1961)

Woolley, Jones \& Happold (1962)

Vishniac \& Trudinger (1962)

T. thioparus isolated by Beijerinck

Beijerinck (1904)

T. thiooxidans isolated by Lipman et al. (1921), Waksman (1922), Waksman \& Joffe (1922)

Waksman \& Starkey (1923)

$T$. thiooxidans isolated by Lipman et al. (1921)

$T$. novellus (culture A) isolated by

Starkey $(1935 b)$

T. thioparus (culture c) isolated by Starkey $(1935 b)$

$T$. novellus isolated by Starkey $(1935 b)$

T. thioparus isolated by Starkey $(1935 b)\}$

T. thioparus isolated by Skarżyński \& I Skarżyński \& Szczepkowski Szczepkowski (1959) (1959)

$T$. thiocyanoxidans isolated by Happold, Johnstone, Rogers \& Youatt
(1954)

Youatt (1954)

T. thioparus ATCC 8158

Peck (1960) 
Table 1 (cont.)

\begin{tabular}{|c|c|c|c|}
\hline \multirow{4}{*}{$\begin{array}{l}\text { Intermediates } \\
\text { Group } 5\end{array}$} & End-products & Organism & Reference \\
\hline & $\begin{array}{l}\text { One or more of the } \\
\text { following: } \\
\text { polythionates, } \\
\text { alkali, sulphate, } \\
\text { sulphur }\end{array}$ & $\begin{array}{l}\text { T. trautweinii (culture B) isolated by } \\
\text { Starkey (1935 } b \text { ) } \\
\text { Culture T isolated by Trautwein (1921) } \\
\text { Culture K isolated by Trautwein (1921) } \\
\text { Pseudomonas aeruginosa } \\
\text { P. fuorescens } \\
\text { Achromabacter stutzeri }\end{array}$ & Starkey $(1934 b, 1985 a)$ \\
\hline & & $\begin{array}{l}\text { M-strains isolated by Parker (1947) } \\
\text { Culture T isolated by Trautwein (1921) } \\
\text { Culture } \mathrm{K} \text { isolated by Trautwein (1921) }\end{array}$ & Parker \& Prisk (1953) \\
\hline & & $\begin{array}{l}\text { Culture } \mathrm{T} \text { isolated by 'Trautwein (1921) } \\
\text { Culture } \mathrm{K} \text { isolated by Trautwein (1921) }\end{array}$ & $\begin{array}{l}\text { Trautwein (1921) quoted } \\
\text { by Starkey }(1934 b, 1935 b)\end{array}$ \\
\hline
\end{tabular}

indicator of thionate production and Pratt (1958) used a test depending on the reaction of polythionates with the Folin-Ciocalteu reagent. Other techniques employed include those of manometry, paper chromatography, paper electrophoresis and the use of radioactive substrate. In manometric investigations Vishniac (1952), Youatt (1954) and Jones \& Happold (1961) used living cells, while Peck (1960) and Peck \& Fisher (1962) used cell-free extracts. Paper chromatographic methods were used by Skarżyński \& Szczepkowski (1959), Jones \& Happold (1961), Woolley, Jones \& Happold (1962) and Trudinger (1961 b). Trudinger also used paper electrophoresis and both he and Skarżyński \& Ostrowski (1958) used labelled thiosulphate as substrate.

During investigations into the bacterial oxidation of spent gas liquor, organisms oxidizing thiosulphate were isolated by the author. The pathway of thiosulphate oxidation was of interest because of the discrepancies already mentioned and in view of the fact that production of polythionates plays an important part in the classification of thiobacilli (Bergey's Manual, 1957). In the work described in this paper a polarographic technique not previously applied to the bacterial oxidation of thiosulphate by pure cultures has been used, supplemented by Starkey's alkali test. It is sensitive, relatively simple and quick; it facilitates the identification of individual polythionates and has both qualitative and quantitative applications.

\section{METHODS}

Organisms. Five strains of autotrophic thiobacilli were used. One strain (т. 1) was isolated from a mixed culture oxidizing thiosulphate, another (T. 2) from a mixed culture oxidizing thiocyanate. Two thiocyanate-oxidizing strains ( T. 3 and T. 4) were isolated from mixed cultures kindly given to the author by the late Miss M. E. Adams of the National Chemical Laboratory, Teddington. A pure culture oxidizing thiosulphate (T. 5) was supplied by Mrs M. Townshend, formerly of the Houldsworth School of Applied Science, University of Leeds. A heterotrophic organism (c) was isolated as a contaminant of a thiosulphate medium. Morphological and biochemical characteristics indicated that T. 1 and T. 5 were strains of Thiobacillus thioparus and that T. 2, T. 3 and T. 4 were strains of T. thiocyanoxidans. Organism c was not classified. Strains were purified by several serial subcultures 
of single colonies on thiosulphate agar and were tested frequently on nutrient agar for possible heterotrophic contamination. Stock cultures were maintained on thiosulphate agar by subculture at 14-day intervals; older cultures quickly became sterile. Throughout a 3-year period of regular subculture there was no evidence of the inter-species change reported by Johnstone, Townshend \& White (1961), or of any variations in the cultural, morphological or biochemical characteristics of any of the strains.

Materials. Analytical grade chemicals were used for media and reagents. Samples of sodium trithionate, sodium tetrathionate and potassium pentathionate were prepared by Miss Mary Seaton (London Research Station, The Gas Council); they behaved characteristically in polarographic tests, although the pentathionate was contaminated with some tetrathionate (Fig. 3, 4 and 5). Membrane filters were obtained from Oxo Ltd.

Media. The liquid thiosulphate medium was similar to but not identical with Starkey's medium 2 (1934a). Its composition was: $\mathrm{KH}_{2} \mathrm{PO}_{4}, 4 \cdot 0$ g.; $\mathrm{Na}_{2} \mathrm{~S}_{2} \mathrm{O}_{3} .5 \mathrm{H}_{2} \mathrm{O}$, 10.0 g.; $\mathrm{MgSO}_{4} .7 \mathrm{H}_{2} \mathrm{O}, 0.1 \mathrm{~g}$.; $\mathrm{CaCl}_{2}, 0.1 \mathrm{~g} . ; \mathrm{NH}_{4} \mathrm{Cl}, 0.1 \mathrm{~g}$; $\mathrm{FeCl}_{3} .6 \mathrm{H}_{2} \mathrm{O}, 0.02 \mathrm{~g}$; $\mathrm{MnSO}_{4} \cdot 4 \mathrm{H}_{2} \mathrm{O}, 0.02 \mathrm{~g}$.; de-ionized water, 1 l. Its $\mathrm{pH}$ was adjusted to $7 \cdot 2-7 \cdot 4$ with sodium hydroxide and it was solidified when necessary by the addition of $10 \mathrm{~g}$. Oxoid ion agar No. 2. Both media were sterilized by autoclaving for $20 \mathrm{~min}$. at a pressure of $10 \mathrm{lb}$./in. ${ }^{2}$.

Nutrient agar in disposable plastic Petri dishes was obtained from Oxo Ltd.

Preparation of test cultures. Sterile 250 or $150 \mathrm{ml}$. conical flasks, containing approximately 100 or $30 \mathrm{ml}$. respectively of sterile liquid thiosulphate medium, were inoculated with a 2- to 7-day thiosulphate culture of the appropriate organism. The inoculated flasks were incubated at $30^{\circ}$, under static conditions or with shaking. After various incubation times, cultures were streaked on nutrient agar to test for contamination; some or all of the culture was then membrane filtered in order to remove organisms and precipitated sulphur. After its $\mathrm{pH}$ had been determined, the filtrate was analysed for polythionates. As preliminary work had shown that no decrease in thiosulphate concentration occurred before the sudden appearance of precipitated sulphur, the first analysis was usually delayed until sulphur had appeared. Except in cultures of the heterotroph (which did not produce sulphur), precipitation normally occurred 1-3 days after inoculation. Nutrient agar plates were examined carefully with a $\times 10$ lens after incubation for 7-14 days. When an autotroph was used as test organism, growth on nutrient agar indicated heterotrophic contamination of the flask culture and analytical data from such cultures were ignored. The occasional growth of very tiny colonies was believed to have been made possible by the carry-over of enough medium with the inoculum to support minimal growth of the autotroph; nevertheless, such growth was regarded as contamination. When the heterotroph was used as test organism, typical growth on nutrient agar and the absence of other growth confirmed the purity of the culture.

\section{Detection of polythionates in culture filtrates}

\section{Polarographic method}

A conventional technique, employing a cell containing a dropping mercury electrode and a saturated calomel electrode, was used in this work; for details of 
the principles and techniques of polarography the reader is referred to standard works by, for example, Kolthoff \& Lingane (1952), Meites (1955), Milner (1957) and Brezina \& Zuman (1958).

Cultures were prepared for analysis by mixing a known volume (1-10 ml.) of culture filtrate with $25 \mathrm{ml}$. of $2 \mathrm{~N}$-diammonium hydrogen phosphate solution (as supporting electrolyte) in a $\mathbf{5 0} \mathrm{ml}$. volumetric flask; the mixture was made up to the mark with de-ionized water and well shaken. The cell was rinsed first with de-ionized water and then with some of the test solution. The rest of the test solution was poured into the cell and de-aerated by bubbling nitrogen through it for $10 \mathrm{~min}$. Rinsing and de-aeration were facilitated by stirring the liquid in the cell magnetically. The time between mercury drops and the temperature of the cell contents were noted.

The same mercury electrode was used throughout the tests. The average time between drops was $c$. 4 sec. but values between $3 \cdot 4$ and $4 \cdot 4$ sec. were noted. At a drop time of 4 sec., $2 \mathrm{mg}$. of mercury dropped per second. The temperature of the cell contents was not controlled but varied only slightly during any one test; it was usually $c .20^{\circ}$ but the range over which tests were conducted was $17-22^{\circ}$. For very accurate analysis, temperature and drop time should be controlled or corrections should be made for any variations.

An increasing negative voltage (over the range 0.0 to -1.5 or $-2.0 \mathrm{~V}$.) was automatically applied to the cell by means of a Tinsley type 15 recording polarograph and direct and derivative polarograms were obtained. For comparison polarograms of the supporting electrolyte, of the thiosulphate medium, and of sodium thiosulphate, tetrathionate and trithionate, and potassium pentathionate solutions were recorded. With diammonium hydrogen phosphate solution as supporting electrolyte, thiosulphate is reduced first, giving an anodic wave with a halfwave potential $\left(\boldsymbol{E}_{\frac{1}{2}}\right)$ of $\boldsymbol{c} . \mathbf{- 0} \cdot \mathbf{0} \mathbf{\mathrm { V }}$; ; tetrathionate, pentathionate and trithionate are then reduced in that order, giving cathodic waves with $E_{\frac{1}{2}}$ values of $c .-0 \cdot 28$, -0.67 , and -1.32 V. respectively (Furness, 1950; Furness \& Davies, 1952; unpublished work by Densham, Seaton \& Noble, London Research Station, The Gas Council). The $E_{\frac{1}{2}}$ values vary slightly with concentration. When the concentration of thiosulphate greatly exceeds that of tetrathionate, the tetrathionate wave may be masked completely by the thiosulphate wave. Using solutions containing known amounts of sodium tetrathionate, a diffusion current of the order of $0.025 \mu \mathrm{A}$. was given by 1 p.p.m. tetrathionate ion. This value was used subsequently for the quantitative determination of tetrathionate in test solutions. The diffusion currents given by known amounts of thiosulphate, trithionate and pentathionate can be measured similarly.

At certain concentrations, maxima are obtained with tetrathionate $(-0.5 \mathrm{~V}$.) and trithionate $(-1.62 \mathrm{~V}$.). These maxima can be suppressed by the use of substances such as gelatin, but their infrequent appearance made such measures unnecessary. With diammonium hydrogen phosphate as electrolyte, small peaks with $E_{\frac{1}{2}}$ values of -0.05 and $-1.4 \mathrm{~V}$. are obtained at high sensitivities; these peaks are due either to the electrolyte itself or to trace impurities in it.

Starkey's alkali test $(\mathbf{1 9 3 4} b)$

A $5 \mathrm{ml}$. sample of culture filtrate was titrated with $0.01 \mathrm{~N}$-iodine, using $1 \%(\mathrm{w} / \mathrm{v})$ sodium starch glycollate as indicator. A second $5 \mathrm{ml}$. volume was boiled for $5 \mathrm{~min}$. 
$1 a$

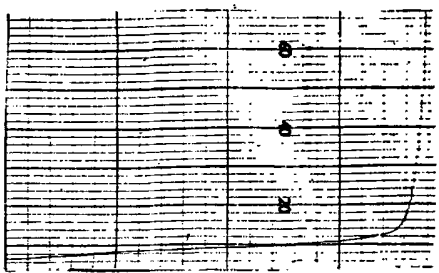

$2 a$

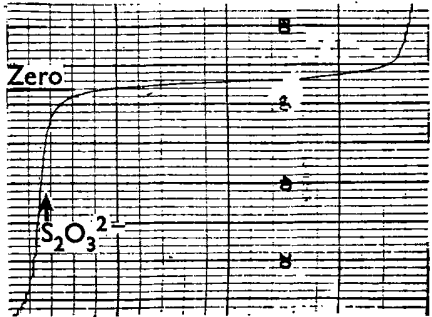

3 a

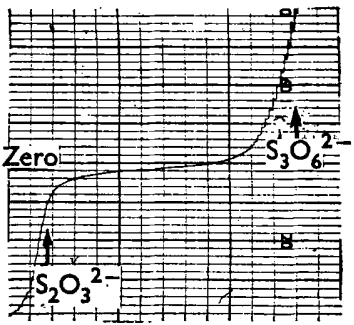

4a

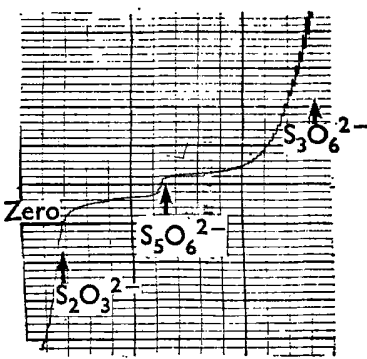

$5 a$

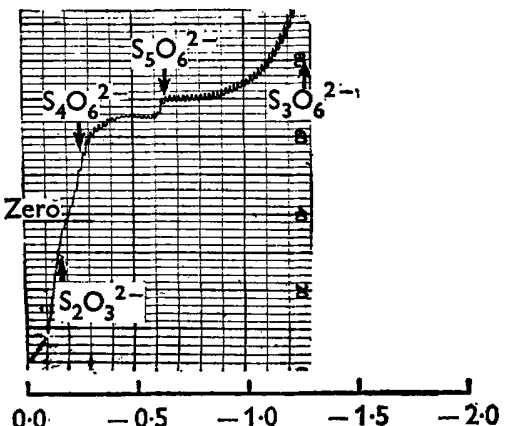

$1 b$

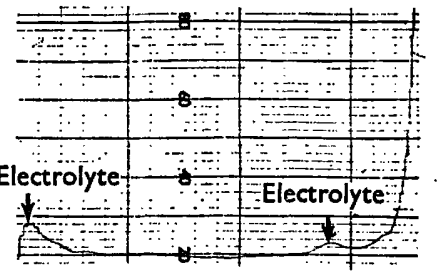

$2 b$

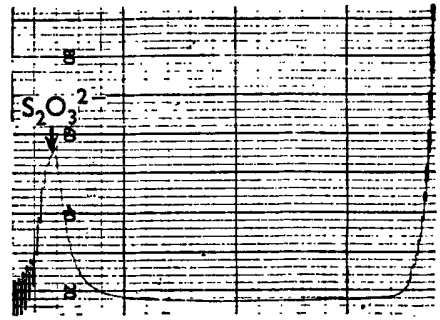

$3 b$

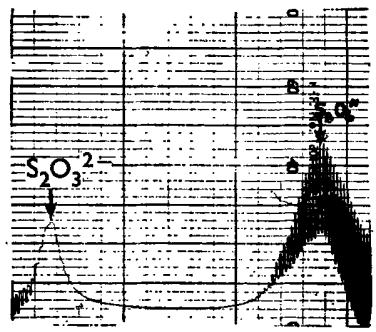

$4 b$

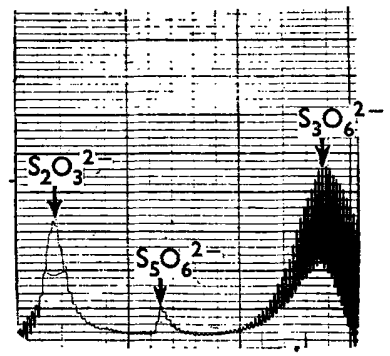

$5 b$

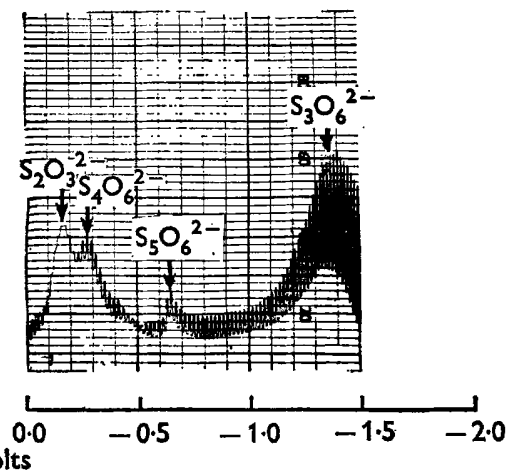

Figs. 1-5. For legend see foot of p. 434 . 

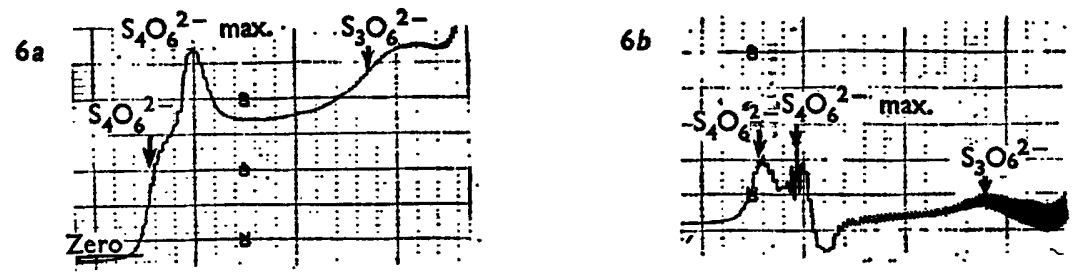

$7 a$

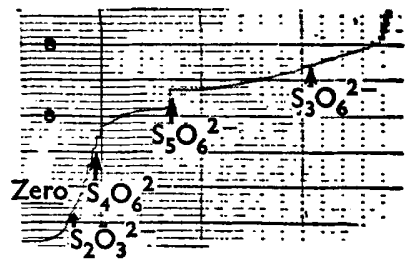

$8 \mathbf{a}$

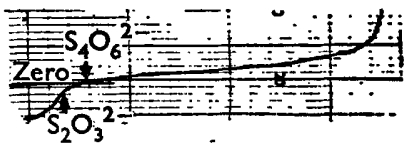

$9 \mathrm{a} \mathrm{S}_{4} \mathrm{O}_{6}^{2}$

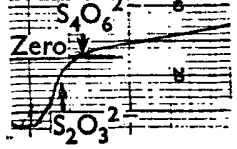

$10 a$

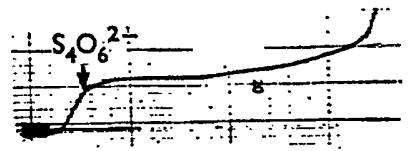

112 年 $\mathrm{S}_{5} \mathrm{O}_{6}^{2-}: \mathrm{S}_{3} \mathrm{O}_{6}{ }^{2-}=\mathrm{I}$

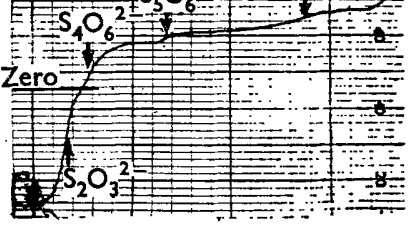

$12 a$

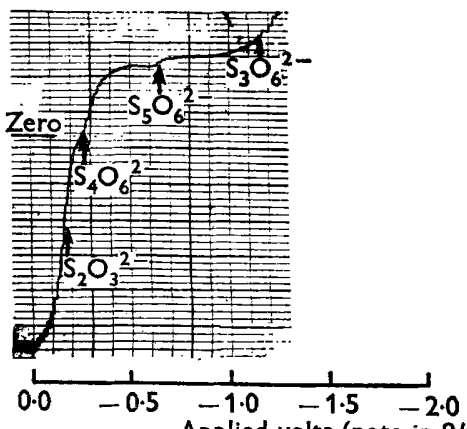

Applied volts (note in $9 b$ voltage scale is halved)
$7 b$

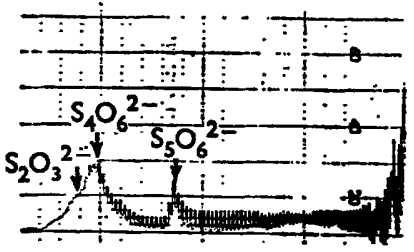

$8 b$

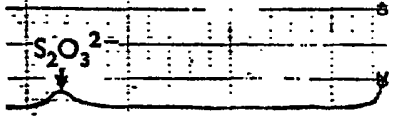

96

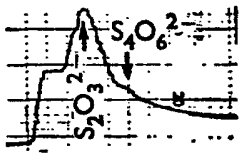

$10 b$

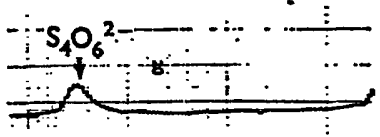

$11 b$

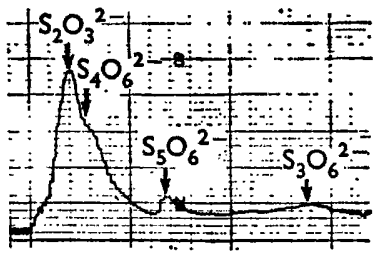

$12 b$.

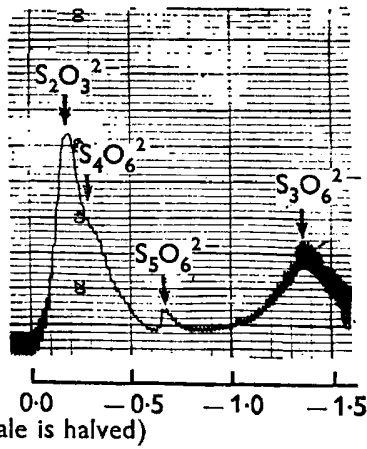

Fig. 6-12. For legend see foot of p. 434. 
with $5 \mathrm{ml}$. of $10 \%(\mathrm{w} / \mathrm{v})$ potassium hydroxide solution and a few $\mathrm{ml}$. of de-ionized water. After cooling, the mixture was neutralized with $10 \mathrm{ml}$. of $10 \%(\mathrm{v} / \mathrm{v})$ acetic acid and titrated with iodine as above. The iodine titre obtained before alkali treatment was subtracted from the titre obtained after treatment; the difference, if any, represented polythionate.

\section{RESULTS}

All the test strains produced tetrathionate and three of them produced trithionate and pentathionate as well. Very much greater concentrations of tetrathionate were detected in cultures of T. 1, T. 5 and organism $\mathrm{c}$ than in cultures of T. 2, т. 3, and T. 4. Acid was produced by all the strains except organism c, which formed alkali.

The results of the various analyses are shown in Table 2 and Figs. 6 to 12. Table 2 records the results for T. 2 only; the results for the other organisms were tabulated in a similar fashion, but only one table has been given as an example. Column $(a)$ shows the differences between actual titration values before and after alkali treatment; these differences should be compared with the differences shown in column $(b)$, which are calculated values based on the concentrations of tetrathionate found polarographically. The calculated differences were usually a little higher than the actual differences. This can be explained if, as was probable, hydrolysis of tetrathionate in the presence of alkali was not quite complete. Since tetrathionate hydrolyses theoretically to give $25 \%$ sulphite and $75 \%$ thiosulphate, and trithionate hydrolyses to give $66 \%$ sulphite and $33 \%$ thiosulphate (Starkey, 1934b), as would be expected the calculated differences were lower than the actual differences in the presence of high concentrations of trithionate (Fig. 12). The polarographic results (Figs. 6 to 12) should be compared with polarograms of the supporting electrolyte (diammonium hydrogen phosphate), of sterile thiosulphate medium and of thiosulphate medium to which trithionate, pentathionate and tetrathionate were added successively (Figs. 1 to 5).

In each of five experiments with T. 1 and six with T. 5 polythionates were detected (Figs. 6 and 11). The differences in iodine titre before and after alkali

\section{EXPLANATION OF FIGS. 1 to 12}

Series $a$. Direct polarograms. The distance between adjacent vertical scale markings represents $0 \cdot 2 \mu \mathrm{A}$. in Figs. 1, 2, 3, 4, 5, 7, 8 and 10, 0.4 $\mu \mathrm{A}$. in Figs. 6, 11 and 12, and $0 \cdot 1 \mu \mathrm{A}$. in Fig. 9.

Series $b$. Derivative polarograms. The distance between adjacent vertical scale markings represents $0.08 \mu \mathrm{A}$. in Figs. 2, 3, 4, 5, 7, 8, 10 and 11, 0.008 $\mu \mathrm{A}$. in Figs. 1 and 9, 0.2 $\mu \mathrm{A}$. in Fig. 6 and $0 \cdot 1 \mu \mathrm{A}$ in Fig. 12.

Fig. 1. Diammonium hydrogen phosphate solution only; this solution is the supporting electrolyte in Figs. 2 to 12.

Fig. 2. Sterile sodium thiosulphate medium.

Figs. 3, 4 and 5. Thiosulphate medium to which sodium trithionate, potassium pentathionate and sodium tetrathionate were added successively.

Fig. 6. Filtrate from a 3-day thiosulphate culture of T. 1 .

Fig. 7. Filtrate from a 5-day thiosulphate culture of $\mathbf{T} .2$.

Figs. 8 and -9. Filtrate from a 5-day thiosulphate culture of T. 3.

Fig. 10. Filtrate from a 4-day thiosulphate culture of т. 4.

Fig. 11. Filtrate from a 4-day thiosulphate culture of т. 5 .

Fig. 12. Filtrate from a 5-day thiosulphate culture of organism c. 
treatment indicated several hundred p.p.m. polythionate in the culture filtrates. Polarographic analyses confirmed the presence of tetrathionate, trithionate and pentathionate. There was always more tetrathionate (up to 1690 p.p.m. for T. 1 and up to 1840 p.p.m. for т. 5) than trithionate and pentathionate, although the concentrations of these were not determined. The lowest $\mathrm{pH}$ values noted were $\mathbf{3 \cdot 2}$ for T. 1 and 2.9 for T. 5. The $\mathrm{pH}$ tended to remain neutral in cultures which were incubated without shaking, although in one test it dropped to 2.9 after incubation for 20 days.

Table 2. The oxidation of thiosulphate by organism 7.2

\begin{tabular}{|c|c|c|c|c|c|c|c|c|c|c|}
\hline \multirow[b]{3}{*}{$\begin{array}{c}\text { Experi- } \\
\text { ment }\end{array}$} & \multirow[b]{3}{*}{$\begin{array}{c}\text { Method } \\
\text { of } \\
\text { aeration }\end{array}$} & \multicolumn{5}{|c|}{$\begin{array}{l}\text { Titration of } 5 \mathrm{ml} \text {. } \\
\text { culture filtrate with } \\
0.01 \mathrm{~N} \text {-iodine }\end{array}$} & \multirow{2}{*}{\multicolumn{4}{|c|}{$\begin{array}{c}\text { Polarographic analyses. } \\
\text { Waves given by }\end{array}$}} \\
\hline & & Incuba- & & $\mathrm{pH}$ & $\begin{array}{c}(a) \\
\text { Difference } \\
\text { in titration } \\
\text { before } \\
\text { and after }\end{array}$ & $\begin{array}{c}(b) \\
\text { Difference } \\
\text { in titration } \\
\text { before } \\
\text { and after } \\
\text { alkali } \\
\text { treatment } \\
\text { (ml.) calcu- } \\
\text { lated from }\end{array}$ & & & & \\
\hline & & $\begin{array}{l}\text { tion } \\
\text { time } \\
\text { (days) }\end{array}$ & $\begin{array}{l}\text { Purity } \\
\text { of } \\
\text { culture }\end{array}$ & $\begin{array}{l}\text { of } \\
\text { culture } \\
\text { filtrate }\end{array}$ & $\begin{array}{l}\text { alkalı } \\
\text { treatment } \\
\text { (ml.) }\end{array}$ & $\begin{array}{l}\text { polarographic } \\
\text { data on } \\
\text { tetrathionate }\end{array}$ & $\begin{array}{l}\text { thio- } \\
\text { sulphate }\end{array}$ & $\begin{array}{l}\text { tri- } \\
\text { thionate }\end{array}$ & $\begin{array}{l}\text { tetra- } \\
\text { thionate* }\end{array}$ & $\begin{array}{l}\text { penta- } \\
\text { thionate }\end{array}$ \\
\hline 1 & Static & 3 & nt & $7 \cdot 0$ & nt & nt & nt & nt & nt & nt \\
\hline & & 9 & + & $6 \cdot 7$ & nt & 0 & + & - & - & - \\
\hline 2 & Static & $\begin{array}{r}3 \\
13\end{array}$ & $\begin{array}{l}\mathrm{nt} \\
+\end{array}$ & $\begin{array}{l}7 \cdot 0 \\
\text { nt }\end{array}$ & $\begin{array}{l}\text { nt } \\
\mathbf{2 \cdot 5}\end{array}$ & $\begin{array}{l}\mathrm{nt} \\
2 \cdot 7\end{array}$ & $\begin{array}{l}\text { nt } \\
-\end{array}$ & $\begin{array}{l}\text { nt } \\
+\end{array}$ & $\begin{array}{l}\text { nt } \\
+350\end{array}$ & $\begin{array}{l}\text { nt } \\
-\end{array}$ \\
\hline 3 & Shaken & 2 & + & $5 \cdot 3$ & $6 \cdot 3$ & $6 \cdot 9$ & + & $?$ & +885 & + \\
\hline 4 & Shaken & $\begin{array}{l}2 \\
5\end{array}$ & $\begin{array}{c}\text { nt } \\
+\end{array}$ & $\begin{array}{l}6 \cdot 5 \\
4 \cdot 8\end{array}$ & $\begin{array}{l}0 \\
6 \cdot 4\end{array}$ & $\begin{array}{l}\text { nt } \\
7 \cdot 2 \dagger\end{array}$ & $\begin{array}{l}\text { nt } \\
+\end{array}$ & $\begin{array}{l}\text { nt } \\
?\end{array}$ & $\begin{array}{l}\text { nt } \\
+920\end{array}$ & $\begin{array}{l}\text { nt } \\
+\end{array}$ \\
\hline 5 & Static & 3 & + & $6 \cdot 7$ & 0 & nt & nt & nt & nt & nt \\
\hline 6 & Static & $\begin{array}{r}6 \\
10\end{array}$ & $\begin{array}{c}\text { nt } \\
+\end{array}$ & $\begin{array}{l}\text { nt } \\
4 \cdot 6\end{array}$ & $\begin{array}{l}0 \cdot 3 \\
7 \cdot 5\end{array}$ & $\begin{array}{l}\text { nt } \\
\text { nt }\end{array}$ & $\begin{array}{l}\text { nt } \\
\text { nt }\end{array}$ & $\begin{array}{l}\text { nt } \\
\text { nt }\end{array}$ & $\begin{array}{l}\text { nt } \\
\text { nt }\end{array}$ & $\begin{array}{l}\text { nt } \\
\text { nt }\end{array}$ \\
\hline 7 & Shaken & $\begin{array}{l}4 \\
5 \\
6\end{array}$ & $\begin{array}{l}+ \\
n t \\
+\end{array}$ & $\begin{array}{l}6 \cdot 6 \\
6 \cdot 0 \\
4 \cdot 5\end{array}$ & $\begin{array}{l}0 \cdot 2 \\
0 \cdot 5 \\
0 \cdot 2\end{array}$ & $\begin{array}{l}0 \\
0 \cdot 2 \\
0\end{array}$ & $\begin{array}{l}+ \\
- \\
-\end{array}$ & $\begin{array}{l}- \\
- \\
-\end{array}$ & $\begin{array}{l}- \\
+\end{array}$ & $\begin{array}{l}- \\
-\end{array}$ \\
\hline 8 & Static & $\begin{array}{l}3 \\
7\end{array}$ & $\begin{array}{c}\text { nt } \\
+\end{array}$ & $\begin{array}{l}\text { nt } \\
4 \cdot 0\end{array}$ & $\begin{array}{l}0 \\
3 \cdot 0\end{array}$ & $\begin{array}{l}\text { nt } \\
\text { nt }\end{array}$ & $\begin{array}{l}\text { nt } \\
\text { nt }\end{array}$ & $\begin{array}{l}\text { nt } \\
\text { nt }\end{array}$ & $\begin{array}{l}\text { nt } \\
\text { nt }\end{array}$ & $\begin{array}{l}\text { nt } \\
\text { nt }\end{array}$ \\
\hline 9 & Static & $\begin{array}{l}2 \\
4 \\
6 \\
7\end{array}$ & $\begin{array}{l}\text { nt } \\
\text { nt } \\
\text { nt } \\
+\end{array}$ & $\begin{array}{l}\text { nt } \\
\text { nt } \\
\text { nt } \\
6 \cdot 3\end{array}$ & $\begin{array}{l}1 \cdot 6 \\
0 \cdot 2 \\
0 \cdot 5 \\
1 \cdot 5\end{array}$ & $\begin{array}{l}\text { nt } \\
\text { nt } \\
\text { nt } \\
\text { nt }\end{array}$ & $\begin{array}{l}\text { nt } \\
\text { nt } \\
\text { nt } \\
\text { nt }\end{array}$ & $\begin{array}{l}\text { nt } \\
\text { nt } \\
\text { nt } \\
\text { nt }\end{array}$ & $\begin{array}{l}\text { nt } \\
\text { nt } \\
\text { nt } \\
\text { nt }\end{array}$ & $\begin{array}{l}\text { nt } \\
\text { nt } \\
\text { nt } \\
\text { nt }\end{array}$ \\
\hline
\end{tabular}

+ , Positive; -, not detected; nt, not tested.

* Figures in this column indicate the tetrathionate concentration (p.p.m.) in the culture filtrate.

$\dagger$ See Fig. 7 .

Polythionates were demonstrated polarographically in some of the tests with T. 2 and their presence was confirmed using Starkey's method (Table 2 and Fig. 7). Tetrathionate predominated in the filtrate, in concentrations of up to 920 p.p.m. Trithionate and pentathionate were barely discernible in the polarograms and their concentrations were therefore very low. The $\mathrm{pH}$ did not fall below 4.0. 
In ten experiments with T. 3, polythionates were not detected by Starkey's method but 19 p.p.m. tetrathionate in the filtrate was indicated polarographically on one occasion (Fig. 8 and 9 ) and 8 and 2 p.p.m. tentatively on two other occasions. In two of eight experiments with T. 4, polarographic analyses revealed tetrathionate at concentrations in the filtrate of 125 p.p.m. (Fig. 10) and c. 3 p.p.m.; these amounts were not detected by Starkey's test. The lowest pH values noted were 4.5 for T. 3 and 4.4 for т. 4 . Trithionate and pentathionate were not found in cultures of either organism.

In the six experiments with organism c, both methods indicated the accumulation of several hundred p.p.m. polythionate, with tetrathionate predominating in concentrations up to 2300 p.p.m. The concentration was 1460 p.p.m. in Fig. 12. The $\mathrm{pH}$ rose; the highest value noted was $8 \cdot 7$.

Sulphur was precipitated in cultures of all the thiobacilli but not in cultures of the heterotroph c. The amount of sulphur was always sufficient to be unmistakable and gave the liquid medium a typical creamy appearance.

Sulphur was also formed abundantly within colonies of the autotrophs on thiosulphate agar.

\section{DISCUSSION}

The occurrence of tetrathionate, sulphur and acid in thiosulphate cultures of the autotrophs and the occurrence of tetrathionate and alkali in cultures of the heterotroph suggests that the autotrophs belong to group 1 and the heterotroph to group 5 (Table 1). For reasons given below, the author believes that tetrathionate and sulphur are formed biochemically but that trithionate and pentathionate have a purely chemical origin.

Nobody who has found tetrathionate in bacterial cultures has suggested that it is not a genuine intermediate in the oxidation of thiosulphate and it is of interest that, during investigations involving more than twenty strains of autotrophic thiobacilli, White \& Hutchison have not found any strains which do not produce polythionates (White, pers. comm., 1963). An enzyme catalysing the oxidation of thiosulphate to tetrathionate has been found in Thiobacillus X (Trudinger $1961 a$, $b$ ), in $T$. thioparus and in autotrophically grown $T$. novellus (Vishniac \& Trudinger, 1962), as well as in many other biological systems. However, the failure of some workers to detect tetrathionate has led to the postulation of alternative pathways not involving this compound (Table 1). In the author's opinion, the factors contributing to failure to detect tetrathionate include the inability of some cultures to accumulate polythionate, the lack of frequent testing and the use of tests of low sensitivity. Much the same views have been expressed by Parker \& Prisk (1953), who commented on the transient appearance of polythionates in some cultures, and by Vishniac \& Santer (1957).

If tetrathionate is a genuine intermediate, the reason for the accumulation of more of it within a given time in cultures of Thiobacillus thioparus than in cultures of $T$. thiocyanoxidans is not clear. One possible explanation is that, though the same pathway may be followed, the rates of reaction differ because of inherent differences between the strains in, for example, cell-wall composition and permeability. Pratt (1958) and Jones \& Happold (1961) also found that cultures of $T$. thiocyanoxidans produced less polythionate than cultures of $T$. thioparus. Jones 
\& Happold expressed the view that the type of polythionate which accumulates is influenced by the ratio between potassium and sodium in the medium and that the phosphate concentration also has an effect on polythionate formation.

Although the occurrence of tetrathionate in cultures has been accepted as evidence of its intermediate role, this is not so with trithionate, pentathionate and sulphur. These have been shown to be formed chemically from tetrathionate (Tamiya, Haga \& Huzisige, 1941; Parker \& Prisk, 1953) and from mixtures of thiosulphate and tetrathionate (Vishniac, 1952). Skarżyński \& Szczepkowski (1959) also detected hexathionate and possibly heptathionate in a mixture of thiosulphate and tetrathionate. Although solutions of polythionates are unstable, trithionate, pentathionate and sometimes dithionate and sulphur have nevertheless been considered by some of these workers and by others to be true intermediates in the bacterial oxidation of thiosulphate.

In the present work, trithionate and pentathionate appeared only after tetrathionate had accumulated and once they had formed there was little or no further change in their concentrations over a period of several days. Furthermore, if only small amounts of tetrathionate formed, trithionate and pentathionate were not produced at all or were produced in such low concentrations that they could not be detected.

The sulphur which was precipitated in cultures of the autotrophs appeared most rapidly in shaken cultures and in cultures which had received a large young inoculum; the results indicated that sulphur formation occurred at neutral as well as acid $\mathrm{pH}$ values.

If sulphur is produced chemically, it should be associated always with mixtures of polythionates and thiosulphate, but it was not produced in cultures of the heterotroph $\mathrm{c}$ or in any of the filtrates which contained abundant polythionates and from which the sulphur and organisms had been removed by membrane filtration. Nor was it produced in some of the polythionate-forming cultures of Parker \& Prisk (1953) and of Baalsrud \& Baalsrud (1954).

This paper is published by permission of The Gas Council. I wish to thank Mr T. G. Noble for practical assistance and advice and for the interest he has taken in this work.

\section{REFERENCES}

BaAlsrud, K. (1954). Some aspects of the physiology of thiobacilli. In Autotrophic Micro-organisms. Symp. Soc. gen. Microbiol. 4, 54.

BaAlsrud, K. \& BaAlsrud, K. S. (1954). Studies on Thiobacillus denitrificans. Arch. Mikrobiol. 20, 34.

BeiJerinck, M. W. (1904). Über die Bakterien, welche sich im Dunkeln mit Kohlensäure als Kohlenstoffquelle ernähren können. Z Zbl. Bakt. (2 Abt. Orig.), 11, 593.

Bergey's Manual of Determinative Bacteriology (1957). 7th edition. Ed. by R. S. Breed, E. G. D. Murray \& N. R. Smith. London: Ballière, Tindall and Cox Ltd.

Brezina, M. \& Zuman, P. (1958). Polarography in Medicine, Biochemistry and Pharmacy. New York: Interscience Publishers Inc.

Furness, W. (1950). The analysis of commercial dithionates and related compounds by polarographic methods. J. Soc. Dy. Col. 66, 270.

Furness, W. \& Davies, W. C. (1952). Polarography of the tetrathionate ion. Analyst, 77,697 . 
Happold, F. C., Johnstone, K. I., Rogers, H. J. \& YouatT, J. B. (1954). Isolation and characteristics of an organism oxidizing thiocyanate. J. gen. Microbiol. 10, 261.

Happold, F. C., Jones, G. L. \& Pratt, D. B. (1958). Utilization of thiocyanate by Thiobacillus thioparus and $T$. thiocyanoxidans. Nature, Lond. 182, 266.

Johnstone, K. I., Townsend, M. \& White, D. (1961). Inter-species change in thiobacilli. J. gen. Microbiol. 24, 201.

Jones, G. L. \& HAPPOLD, F. C. (1961). The occurrence of polythionates as intermediates in the metabolism of thiosulphate by the thiobacilli. J. gen. Microbiol. 26,361 .

Kolthoff, I. M. \& Lingane, J. J. (1952). Polarography, vols. 1 and 2. New York: Interscience Publishers Inc.

LEes, H. (1955). Biochemistry of Autotrophic Bacteria. London: Butterworths Scientific Publications.

Lipman, J. G., Waksman, S. A. \& Joffe, J. S. (1921). The oxidation of sulphur by soil micro-organisms. Soil Sci. 12, 475.

Meites, L. (1955). Polarographic Techniques. New York: Interscience Publishers Inc.

Minner, G. W. C. (1957). The Principles and Applications of Polarography and other Electroanalytical Processes. London: Longmans, Green and Co. Ltd.

Nathansohn, A. (1902). Über eine neue Gruppe von Schwefelbakterien und ihren Stoffwechsel. Mitt. zool. Sta. Neapel, 15, 655.

Parker, C. D. (1945). The corrosion of concrete. I. The isolation of a species of bacterium associated with the corrosion of concrete exposed to atmospheres containing hydrogen sulphide. Aust. J. exp. Biol. med. Sci. 23, 81.

Parker, C. D. (1947). Species of sulphur bacteria associated with the corrosion of concrete. Nature, Lond. 159, 439.

Parker, C. D. \& Prisk, J. (1953). The oxidation of inorganic compounds of sulphur by various sulphur bacteria. J. gen. Microbiol. 8, 344.

PECK, H. D. (1960). Adenosine 5'-phosphosulphate as an intermediate in the oxidation of thiosulphate by Thiobacillus thioparus. Proc. nat. Acad. Sci., Wash. 46, 1053.

Peck, H. D. (1962). Symposium on metabolism of inorganic compounds. V. Comparative metabolism of inorganic sulphur compounds in micro-organisms. Bact. Rev. 26, 67.

Peck, H. D. \& Fisher, E. (1962). The oxidation of thiosulphate and phosphorylation in extracts of Thiobacillus thioparus. J. biol. Chem. 237, 190.

PratT, D. B. (1958). Detection of polythionate in cultures of thiobacilli by means of the Folin-Ciocalteu reagent. Nature, Lond. 181, 1075.

Santer, M., Margulies, M., Kinnman, N. \& Kaback, R. (1960). Role of inorganic phosphate in thiosulphate metabolism by Thiobacillus thioparus. J. Bact. 79, 313.

SKarży ́̇ski, B. \& Szczepkowski, T. W. (1959). Oxidation of thiosulphate by Thiobacillus thioparus. Nature, Lond. 183, 1413.

Skarżý̇skI, B. \& Ostrowski, W. (1958). Incorporation of radioactive sulphur by Thiobacillus thioparus. Nature, Lond. 182, 933.

STARkEy, R. L. $(\mathbf{1 9 3 4} a)$. Cultivation of organisms concerned in the oxidation of thiosulphate. J. Bact. 28, 365.

Starkey, R. L. (1934b). The production of polythionates from thiosulphate by microorganisms. J. Bact. 28, 387.

Starkey, R. L. $(1935 a)$. Products of the oxidation of thiosulphate by bacteria in mineral media. J. gen. Physiol. 18, 325.

StaRkey, R. L. $(1935 b)$. Isolation of some bacteria which oxidize thiosulphate. Soil Sci. 39, 197 .

StaRkey, R. L. (1956). Transformations of sulphur by micro-organisms. Industr. Engng Chem. 48, 1429.

Tamiya, H., Haga, K. \& Huzisige, H. (1941). Zur Physiologie der chemoautotrophen Schwefelbakterien. Acta phytochim. Tokyo, 12, 173. (Quoted by Vishniac \& Santer, 1957.)

Trautwein, K. (1921). Beitrag zur Physiologie und Morphologie der Thionsäurebakterien (Omelianski). Zbl. Bakt. (2. Abt. Orig.), 53, 513.

Trudinger, P. A. (1959). Initial products of thiosulphate oxidation by Thiobacillus $\mathrm{X}$. Biochim. biophys. Acta, 31, 270. 
Trudinger, P. A. $(1961 a)$. Thiosulphate oxidation and cytochromes in Thiobacillus $\mathbf{X}$. I. Fractionation of bacterial extracts and properties of cytochromes. Biochem. $J$. 78, 673.

Trudinger, P. A. (1961 b). Thiosulphate oxidation and cytochromes in Thiobacillus X. II. Thiosulphate-oxidizing enzyme. Biochem. J. 78, 680.

Vismuiac, W. (1952). The metabolism of Thiobacillus thioparus. I. The oxidation of thiosulphate. J. Bact. 64, 363.

Vishniac, W. \& Santer, M. (1957). The 'Thiobacilli. Bact. Rev. 21, 195.

Vishniac, W. \& Trudinger, P. A. (1962). Symposium on autotrophy. V. Carbon dioxide fixation and substrate oxidation in the chemosynthetic sulphur and hydrogen bacteria. Bact. Rev. 26, 168.

Waksman, S. A. (1922). Micro-organisms concerned in the oxidation of sulphur in the soil. I. Introductory. J. Bact. 7, 231.

Waksman, S. A. \& JofFe, J. S. (1922). Micro-organisms concerned in the oxidation of sulphur in the soil. II. Thiobacillus thiooxidans, a new sulphur-oxidizing organism isolated from the soil. J. Bact. 7, 239.

Waksman, S. A. \& Starkey, R. L. (1923). On the growth and respiration of sulphuroxidizing bacteria. J. gen. Physiol. 5, 285.

Woolley, D., Jones, G. L. \& Happold, F. C. (1962). Some metabolic differences between Thiobacillus thioparus, T. denitrificans and T. thiocyanoxidans. J. gen. Microbiol. 29, 311.

YoUATT, J. B. (1954). Studies on the metabolism of Thiobacillus thiocyanoxidans. J. gen. Microbiol. 11, 139. 